\title{
Information Model for Global Seaborne Shipping from 2010 to 2020
}

\author{
Vinko Vidučića, Mihaela Bukljaš Skočibušićb, Jelena Žanić \\ Mikuličića
}

The research has focused on the development of the global seaborne shipping market from 2010 to 2020. The analysis and assessment of the relevant variables of the model and the resulting growth rates have been aimed at a scientific formulation of the research findings and have been used to describe the most important theoretical principles governing the global seaborne shipping market over the defined period of time.

The basic hypothesis has been confirmed through the direct growth rates of the selected model variables. In this way a scientific confirmation of the hypothesis has been provided: "On the basis of scientific insights into the global seaborne shipping market, it is possible to suggest a new information model for the development of the global seaborne shipping market for the period 2010 - 2020."

\section{KEY WORDS}

$\sim$ Seaborne shipping

$\sim$ Freight rates

$\sim$ Shipbuilding

$\sim$ Economy.

\section{INTRODUCTION}

Trends in seaborne shipping depend upon the rate of economic development, economic structure, and political situation in the countries that participate in the international maritime trade. The economic growth of the most developed countries is tightly related to the current state of the most cost-effective shipping routes. The busiest seaways follow the shorelines of Asia, Europe, and the eastern coastlines of the USA. The basic hypothesis of this research assumes that scientific insights into the global maritime market can enable the design of a new information model for the development of the global seaborne shipping market for the period 2010-2020. The research involves a number of scientific methods, among which the most relevant are analysis and synthesis, induction and deduction, descriptive, comparative, statistical, and mathematical methods, method of model drawing (growth matrix), and methods of proving and refuting.

Prior to drawing up a model for the global seaborne shipping market and calculating the relevant direct growth rates, the critical variables of the model need to be set. The design of the model is based upon the following variables: Global economy, Globalisation, Freight rates, Tanker trade, LNG trade, Bulk trade, Container trade, Passenger trade, Shipbuilding, and Innovations in maritime shipping. Values of the selected variables have been entered into the model on the basis of mental-verbal insights into the global maritime market. Calculation of the direct growth rates allows tracing of the changes in the variable growth intensity and structural relationships among the variables. Finally, a scientifically founded verification of the basic scientific hypothesis of this discussion is presented. 


\section{GLOBAL SEABORNE SHIPPING MARKET}

Global seaborne shipping market can be defined as the global market of maritime shipping and shipbuilding. The demand on the global market of shipping capacity depends on the international seaborne trade, while the supply is defined by the world merchant fleet. In maritime shipping business, the main revenues are provided through freight rates, i.e. through the price of seaborne shipping service. This is the primary mechanism that encourages the shippers' investments in the business (Vidučić, 2011).

\subsection{Global Economy}

In the early 2010 the world economy stood better than expected, but gradually got weaker towards the end of the year. Deterioration of the global economy and adverse trends in Europe's economy affected the developing countries, but their growth rates remained high so that these countries became increasingly important for the overall growth of the global economy (Udruga pomorskih kapetana - glasnik udruge web page, 2012). However, predictions about the trends in global maritime shipping remain difficult and unrewarding (Glavan, 1992). A summary of forecasts for the global seaborne shipping leads to the assumption that the environment protection costs will increase due to construction of the eco-friendly tonnage, that the price of gas will affect the decisions associated with investments in alternative fuels, that the relationship between GDP and maritime shipping demand will change, and that the unexpected events (e.g. political circumstances, such as recent events in Russia and the Near East) will be crucial (DNV web page, 2015). Around $90 \%$ of the foreign trade of the USA, European Union, and developed Asian countries is performed by sea and through seaports. As the global trade rises, the seaports handle more and more cargo. The trend will slightly grow by 2020. A study carried out by the Finnish Ministry of Transport and Communications in January 2005 predicted that the export from the EU to the fast growing economies (Russia, India, China, and other Asian countries) would triple, and the import would double by 2030 (not including energy products) (Kunda, 2013).

\subsection{Globalisation}

It is unrewarding to try to comprehend the overall impacts of globalisation but, looking from today's perspective, it is very likely that the effects might include "prevailing of the existing national borders, decline of sovereignty of the states-nations, and establishment of global and supranational associations that would take over the regulatory and other functions in the global economy and society" (Puljiz, 1998). Globalisation is a process developing beyond national borderlines, leading to economic, political, cultural, ecological, and information activities across the world and resulting in the global interdependence of the society. It strongly affects the development of maritime shipping in an interactive way. Maritime shipping might be regarded as an instrument of the process (Stopford, 2003). Global trends involve deregulation and abolition of national barriers, thus affecting seaborne shipping as well. The World Trade Organisation (WTO) has launched a process of liberalisation of trade and deregulation of maritime shipping. The liberalisation has resulted in the increased use of flags of convenience, open registers of shipping, and outsourcing. Specialisation in individual segments of seaborne shipping enables the outsourcing and off-shoring of management functions in all geographic combinations. The process of globalisation has encouraged the transfer of registryof vessels, from national to open registries. It is assumed that half of the world merchant fleet flies flags of convenience. Future agreement on free trade between the USA and EU is also part of the globalisation process. The agreement will increase the flow of goods by sea, across the Atlantic Ocean (European Commission home page, 2015).

\subsection{Freight Rates}

The global crisis that started shaking the worldwide economy in 2008 was the most severe crisis since the Great Depression in the 1930s. It hit hard the seaborne trade. Freight rates plunged, banks reduced financing of the maritime trade, orders were cancelled, and a number of renowned shippers disappeared from the market (Stopford, 2009). Most shippers responded by using economical sailing speeds and adjusted their shipping schedules accordingly. Reduced fuel consumption helped to mitigate huge oscillations in fuel prices on the global oil market. The economical speed is about $20 \%$ less than the full speed used before the economic crisis (Mitrović, 2006). The year of 2010 experienced low freights and surplus shipping capacity. However, by the end of that year the global exchange of goods increased by $5 \%$ and was $6 \%$ higher than before the crisis. The worldwide tonnage grew by $9 \%$, i.e. 120 million dwt. By February 2012 the downward trend in freight rates continued and reached only $36 \%$ of the rates before the crisis, while the price of secondhand vessels fell by $3 \%$. In February 2012, heavy fuel oil prices reached record values, skyrocketing to over 700 USD/t. The combination of high fuel prices and low freight rates caused financial troubles for all shippers. Due to requirements for finding balance between the worldwide tonnage and shipping demand, changes for the better are expected in the years to come. In 2013, the highest growth of freight rates was experienced in bulk and container trade. Seaborne trade in 2014 was better than ever but the shippers coped with surplus capacities of the ships that had been commissioned by 2008 , in the time of high freights, and with reduced demand from China. In February 2015, the Baltic 
future trends on the LNG market. For instance, fifteen years ago it was forecasted that the USA would import 40 million cubic meters of LNG in 2010. As the year of 2010 was passing, it turned out that the import reached only half of what had been expected. More moderate forecasts predict that the US export of LNG will considerably drop due to political reasons and the nation's own demand for gas. In other words, over the next ten years the US annual export of LNG will not exceed 40 percent of Qatar's current annual export. Even these forecasts are considered as very optimistic. (Tijardović, 2012).

\subsection{Bulk Trade}

Trends in bulk shipping present the backbone of the international seaborne trade. Presently, the demand is growing rather fast. Following the worldwide 2008-2009 economic crisis, freight rates in the bulk segment plunged in 2010 (DNV home page, 2015). In 2013, bulk shipments amounted to 6.7 billion tons, a $5.5 \%$ increase compared to 2012. There is a wide range of importers on the market. The most important include Argentina, Australia, Brazil, Canada, Indonesia, South Africa, and the United States of America. However, there are smaller importers emerging on the market, as well as new suppliers, such as Liberia, Peru, and Sierra Leone, taking their market share. In the world orderbook for 2015 there are altogether 1,958 bulk carriers with around 163 million dwt (21\% of the current fleet), including 351 orders placed for Capesize vessels (over 100,000 dwt), i.e. $22 \%$ of the current fleet of Capesizes, 400 orders placed for Panamaxes $(65,000-100,000 \mathrm{dwt})$, i.e. $17 \%$ of the current Panamax bulk fleet, and 644 orders placed for Handymax ships (40,000 - 65,000 dwt), which represents $27 \%$ of the current Handymax fleet (Hrvatska brodogradnja jadranbrod d.d. home page, 2015). By 2020, the economies of China, India, and Brazil will continue to strengthen the bulk fleet due to high growth of their annual GDPs. Over the next five years it is expected that China will need bulk carriers for importing raw materials from distant sources. The trade between Africa and Asia will intensify, resulting in the growth of the bulk market. Building of bulk carriers having the capacity over 200,000 dwt is expected. The increased demand of the world elementary industries for coal as the basic energy product results in the increased share of the tramp trade. It is expected that the demand in the segment of tramp trade will grow more intensely than the demand in other market segments (Hrvatska brodogradnja jadranbrod d.d. home page, 2015) .

\subsection{Container Trade}

Five years ago the container seaborne shipping fleet amounted to $450,053 \mathrm{dwt}$. Four years ago the fleet capacity rose to $474,846 \mathrm{dwt}$, while three years ago the container trade capacity amounted to $507,453 \mathrm{dwt}$. The trend of growth is obvious. After a period of stagnation, it is expected that the container trade market will grow by $6.7 \%$ in 2015. According to the results produced by the research carried out by Clarkson Company, from $1^{\text {st }}$ April 2011 to $31^{\text {st }}$ March 2014 there were 291 orders for post-Panamax and large container ships placed worldwide. It is interesting to note that only five orders were placed with South Korean shipbuilders. The trend started in 2011 by the Maersk Company placing ten orders for super-large container carriers having an average capacity of 18,270 TEU. The United Arab Shipping Company, which provides shipping services for six Near East countries, including Kuwait, placed orders for six 18,000 TEU and eleven 14,000 TEU carriers at the end of 2014 and in early 2015. Meanwhile the Canadian company Seaspan commissioned fifteen 14,000 TEU and twelve 10,000 TEU carriers and plans to purchase 20 more mega-carriers by early 2016. Asian shippers follow the trend. However, it is worth noting here that South Korean shippers did not place orders for large vessels, except for Hyundai Merchant Marine which commissioned five 13,100 TEU container carriers, whereas Hanjin Shipping, the largest South Korean shipping company, did not place any order (UNSCIMEDIA homepage, 2015). Presently, the worldwide orders amount to 3.39 million TEU, i.e. $18.4 \%$ of the current capacity, which is the lowest ratio since 2000. According to the 2015 data, APM Maersk operates most of container carriers -608 vessels. The Mediterranean Shipping Company, with 505 container carriers, is the world's second-largest shipping line in terms of container vessel capacity. CMA CGM Group has 459 vessels, Evergreen Line 199, Hapag Lloyd 184, Cosco Container 160, PIL (Pacific International Line) 150, CSCL 141, Hamburg Sud Group 114, while MOL operates 112 vessels (Statista - The statistics Portal homepage, 2015). Currently the busiest container routes run from Asia to Europe (14.1\%), from Asia to North America (13.8 \%), North America - Asia (7.4 \%), Europe - Asia (6.4\%), Europe - North America (3.8\%), and from North America to Europe (2.8\%). By the year of 2020, further strengthening of the Asian and European markets, employment of larger vessels, and new Panamax standards of 12,500 TEU are expected. Vessels whose capacities are less than 1000 TEU will represent a negligible share of the market. It is also expected that, over the next five years, only 4 or 5 out of ten major container shippers will survive.

\subsection{Passenger Trade}

Passenger trade has considerably recovered after the 2009 depression caused by global recession. The number of passengers booking cruise travels increased steadily, from 15.62 million in 2007 to 21.12 million in 2013. The worldwide cruise ship fleet grew from 2012 to 2013 by $3.3 \%$, reaching 20.9 million dwt. Global cruise industry earned 36.27 billion USD in 2013. In the period from 2016 to 2018 the Royal Caribbean International is planning to invest in a newbuild cruise ships more than any other shipper (Cruise Industry News, 2015). As the number of passengers 
increases every year, it is expected that their number will amount to 24 million by 2018 . North America is the leading cruise market. Mintel estimates that the value of the North American market will reach almost 50 billion USD by 2018. Australia is emerging as the second-largest market. Investments in cruise ships will amount to 12 billion USD over the period 2015-2018 (Ship Cruise home page, 2015). China signed the Memorandum of Understanding with the American cruise shipping company Carnival Corporation with the purpose of transfer of know-how and in order to enable China to build large cruise ships. According to Chinese forecasts, by the year of 2020 China will have become one of the major markets for these vessels, with around 4.5 million passengers. The two largest cruise shipping companies, Carnival Corporation and Royal Caribbean Ltd share $71.7 \%$ of the overall revenues from cruise tourism. It is expected that 19 new cruise ships will contribute towards 64,300 passenger capacities by 2018 (Ship Cruise home page, 2015).

\subsection{Shipbuilding}

There is no telling how many shipyards there were in China, the world's major shipbuilding power, in 2010. Estimations range from 850 to 1500 . More than 100 Chinese shipyards were able to produce vessels larger than $30,000 \mathrm{dwt}$. It was customary to place an order for a newbuilding before a shipyard even existed, because the state provided guarantees. In 2010 there were 400 new buildings worldwide (Izvješće Tankerske plovidbe d.d., 2009). Labour costs in most shipyards currently range from 500 to 1000 USD/CGT. Shipbuilding countries having labour costs over 1000 USD/CGT produce differentiated vessels (cruise ships in Germany, warships in the USA) or disappear from the shipbuilding market (Denmark) (CESA web page, 2010). The world fleet increased by 65.9 million dwt in 2014. When observing the growth over the longer course of time, it can be noticed that the 2014 growth was lower than usual. The 2008 global crisis strongly affected the industry and caused a five-year depression. The trend changed in 2013 and in February 2015 the world orderbook continued to grow. Presently, there are 6.371 orders for newbuild vessels having around 112 million compensated gross tons (cgt), or around $18 \%$ of the current fleet. The quantity of newly ordered ships in the first three quarters of 2014 was larger by 2 million cgt compared to the same period in the previous year, i.e. 2105 ships with 36 million cgt were ordered. The quantity of the delivered ships within the same period was somewhat smaller: the delivered vessels had 28.4 million cgt, which implies a trend of lower demand for newbuild ships, i.e. stagnation on the global market. China ranks first in the number of orders placed for newbuildings and their overall tonnage. This is the first time that South Korea is not ranked first (Research and Markets, 2015).
Table 1 shows that bulk carriers make over $50 \%$ of the world's newbuildings ordered at the end of 2014. Presently, there are about 800 shipyards in China. The designed shipbuilding policy, aimed at solving the overcapacity problems, and at preserving the industry in line with the market principles, will result in the survival of around 50 shipyards. These measures will mostly affect small and middle-sized shipyards. The financing of shipbuilding presents the toughest obstacle to entering the market of high-tech vessels (Vidučić, 2011).

Table 1.

World orderbook, November 2014.

Source: http://www.hb.hr

\begin{tabular}{lll} 
Ship type & Quantity ordered & DWT \\
\hline Bulk carrier & 2028 & $170 \mathrm{mil}$ \\
\hline Tanker & 933 & $74 \mathrm{mil}$ \\
\hline Container ship & 452 & $39 \mathrm{mil}$ \\
\hline LPG carrier & 368 & $18 \mathrm{mil}$ \\
\hline Cruise ship & 28 & $6 \mathrm{mil}$ \\
\hline
\end{tabular}

The year of 2013 was a milestone in the market of newbuild and second-hand vessels. From the very beginning of that year it was clear that the activities would intensify on the market due to a drop in the yen and, more directly, due to increased activities on the bulk shipping market. Dramatic changes resulted in filling the orderbooks until the beginning of 2016. The data provided by Intermodal show that more than 2000 orders for newbuild ships were placed in 2013 (Columbia River Log Scaling \& Grading Bureau home page, 2015). New regulations regarding the environment protection have been imposed causing an increased demand for new types of vessels able to reduce fuel consumption considerably (Mitrović, 2005).

Commissioning and deliveries of vessels able to reduce their direct harmful impact on the environment will intensify by 2020. These "green" ships are relatively cheap due to the situation in the shipbuilding industry (decline in European shipbuilding and blooming shipbuilding in Asia). Moreover, they are economical because they reduce fuel consumption, which is the highest single operating cost in maritime shipping. Despite the excess capacity of the world fleet, vessels of the new generation have been commissioned. The trend is likely to gradually displace standard vessels out of the market (DNV home page, 2015).

\subsection{Innovations in Maritime Shipping}

All tanker shippers had to replace their single-hull ships with double-hull tankers by 2010. In 2012, international 
regulations required a reduction in sulphur content in fuel to $3.5 \%$, whereas in 2015 the sulphur content in fuel will have to be further reduced to $0.1 \%$ at the US eastern shores, the North Sea, the Baltic, and the English Channel (La Manche). It is expected that the issues regarding the change of fuel will be solved by 2020. The problems include the loss of propulsion, fluctuation of ship speed at lower loads, difficulties in starting and reversing operations, and inability to reach full speeds. It is expected that, as from $1^{\text {st }}$ January 2020, the sulphur content in fuel will decrease by $0.5 \%$ globally. Alternative means of reducing sulphur emissions will be allowed, including scrubbers and exhaust gas purification systems (DNV home page, 2015). According to DNV Shipping 2020 report, more than 1 in 10 newbuildings will be delivered with gas fuelled engines, the demand for marine distillates could be as high as 200-250 million tonnes annually, newbuildings in 2020 will emit up to 10 to $35 \%$ less CO2 than today's ships, the Energy Efficiency Design Index (EEDI) will be a driver for more than half of the reduction, and ballast water treatment systems will be installed on at least half of the world fleet (EMSA home page, 2015). The recommendations for the shippers adjusting to market changes until 2020 include the optimisation of ship management (passage planning, impact of weather conditions), continuous market monitoring, introduction of cold standby regime during cargo operations and when in port, whenever possible (power supply from ashore), setting and monitoring the efficiency parameters, use of new and more efficient hull paints, replacement of old and worn-out machinery and equipment with new energy-saving products, optimisation of the overall supply chain and fleet distribution (cooperation with cargo suppliers, charterers and agents), implementation of the policy of replacing older ships with eco-friendly vessels, ordering newbuildings that feature efficient construction qualities, suitable selection of human resources, detection of defects and shortcomings and the introduction of necessary changes in the organisation structure of the shipping companies, preparing "green passports", employment of new technologies that are more efficient in terms of energy and ecology (WHR, BWM and equipment, etc.), reduction of fossil fuel consumption and use of alternative sources. Shippers should introduce these guidelines in their development plans (EMSA home page, 2015).

\section{DESIGNING THE INFORMATION MODEL FOR GLOBAL SEABORNE SHIPPING MARKET 2010-2020}

Quantification of the information model for global seaborne shipping market 2010 - 2020 will result from the qualitative research. The assessment of the variables of the model will take into consideration synergetic effects of the following scientific aspects: scientific theoretical aspects of the individual model variables, values and importance of variables of the model in the observed period, i.e. from 2010 to 2020. The design of the information model for global seaborne shipping market 2010 - 2020 is based on the previously set variables. The variables that are considered critical are: Global economy, Globalisation, Freight rates, Tanker trade, LNG trade, Bulk trade, Container trade, Passenger trade, Shipbuilding, and Innovations in maritime shipping.

It is asserted that the global seaborne shipping market consists of " $n$ " inter-reliant elements. The value of an individual model variable is expressed as $y_{\text {if }}$ and $y_{i t-1}$ of the $i$ variable in the period $t$ and $t-1$. An increase of the input value of the $i$ variable of the model is expressed as:

$\Delta \mathrm{y}_{\mathrm{it}}=\mathrm{y}_{\mathrm{it}}-\mathrm{y}_{\mathrm{it}-1}$

(Vidučić, 2007). An indirect growth rate of the $i$ variable, in relation with $j$, is defined as the relation among the input growth of the $i$ variable of the information model, $\Delta y_{i t}$, and the input value of the $j$ variable of the model in the period $t$, that is, the indirect growth rate is expressed by the equation:

$r_{i j t}=\frac{\Delta y_{i t}}{y_{i t}}$

where: $i, j=1, \ldots, \mathrm{n}$, whereas $y_{i t-1} \neq 0$.

The indirect growth rates can be expressed in a form of the growth matrix of the model variables:

$r_{\mathrm{t}}=\left[\begin{array}{llll}r_{11} & r_{12} & L & r_{1 n t} \\ r_{21} & r_{22} & L & r_{2 n t} \\ L & L & L & L \\ r_{n 1 t} & r_{n 2 t} & L & r_{n n t}\end{array}\right]$

where $t=1, \ldots t$

The variables on the main vertical refer to direct growth rates $(i=j)$. The variables in the $i$ row refer to the input growth in the $i$ variable in relation to inputs in other variables. The variables in $i$ column refer to the value growth of the input in all variables of the model in relation to the input of the $i$ variable in the period $t$. Therefore, each variable in the growth matrix is represented by one row and one column, with elements expressing indirect or relative growth relationships. Other rows and columns refer to other variables of the information model for global seaborne shipping 2010 - 2020. If only the direct growth rates are analysed, then the growth of a variable is expressed irrespective of the growth of other variables. By expressing the direct and indirect rates, it is possible to follow both intensity changes of the growth of variables and their structural relationships at the same time. 
The quantification of the above mentioned variables, on the index scale from zero to 100 , has been performed on the basis of mental-verbal insights into the worldwide maritime shipping market. Zero is the value of the model variables which corresponds to the situation on the seaborne shipping market in 2008, when the global crisis - the most severe crisis since the Great Depression in the 1930s - shook worldwide economies. The value 100 corresponds to the situation on the maritime shipping market before 2008 , i.e. when the freight rates index reached its record high. The model comprises the variables quantified for the year 2010, as well as the expected values of the variables for 2015 and 2020 .

Table 2 shows the growth value of the model variables: 1. Freight rates (50), 2. Innovations in maritime shipping (30), 3. Bulk trade (25), 4. Container trade (20), 5. Global economy (20), 6. Passenger trade (20), 7. LNG trade (10), 8. Shipbuilding (10), 9. Globalisation (10) and 10. Tanker trade (10).

The research has provided the direct growth rates of the model for global seaborne shipping market 2010 - 2020 (Table 3). The model has provided both direct and indirect growth rates of the individual variables. Because of limited space, the indirect growth rates will not be elaborated in this paper.
Table 2.

Values of the variables of the information model for global seaborne shipping market from 2010 to 2020.

\begin{tabular}{|c|c|c|c|c|c|}
\hline \multirow{2}{*}{\multicolumn{2}{|c|}{$\begin{array}{l}\text { Variables of the } \\
\text { information model for } \\
\text { global seaborne shipping } \\
\text { from } 2010 \text { to } 2020\end{array}$}} & \multicolumn{3}{|c|}{ Inputs y } & \multirow{2}{*}{$\begin{array}{l}\text { Growth } \\
\text { 2010/20 }\end{array}$} \\
\hline & & 2010 & 2015 & 2020 & \\
\hline 1. & Global economy & 60 & 70 & 80 & 20 \\
\hline 2. & Globalisation & 70 & 75 & 80 & 10 \\
\hline 3. & Freight rates & 20 & 40 & 70 & 50 \\
\hline 4. & Tanker trade & 70 & 75 & 80 & 10 \\
\hline 5. & LNG trade & 60 & 65 & 70 & 10 \\
\hline 6. & Bulk trade & 40 & 45 & 65 & 25 \\
\hline 7. & Container trade & 50 & 60 & 70 & 20 \\
\hline 8. & Passenger trade & 65 & 75 & 85 & 20 \\
\hline 9. & Shipbuilding & 60 & 65 & 70 & 10 \\
\hline 10. & $\begin{array}{l}\text { Innovations in } \\
\text { maritime shipping }\end{array}$ & 50 & 60 & 80 & 30 \\
\hline
\end{tabular}

Table 3.

Growth rates of the information model of the global seaborne shipping market from 2010 to 2020, on the index scale from zero to 100 .

\begin{tabular}{lllllllllll}
$\begin{array}{l}\text { Model } \\
\text { variables }\end{array}$ & 1 & 2 & 3 & 4 & 5 & 6 & 7 & 8 & 9 & 10 \\
\hline $\mathbf{1}$ & $\mathbf{2 5 , 0}$ & 25,0 & 28,6 & 25,0 & 28,6 & 30,8 & 28,6 & 23,5 & 28,6 & 25,0 \\
\hline $\mathbf{2}$ & 12,5 & $\mathbf{1 2 , 5}$ & 14,3 & 12,5 & 14,3 & 15,4 & 14,3 & 11,8 & 14,3 & 12,5 \\
\hline $\mathbf{3}$ & 62,5 & 62,5 & $\mathbf{7 1 , 4}$ & $\mathbf{6 2 , 5}$ & $\mathbf{7 1 , 4}$ & $\mathbf{7 6 , 9}$ & $\mathbf{7 1 , 4}$ & 58,8 & 71,4 & 62,5 \\
\hline $\mathbf{4}$ & 12,5 & 12,5 & 14,3 & $\mathbf{1 2 , 5}$ & 14,3 & 15,4 & 14,3 & 11,8 & 14,3 & 12,5 \\
\hline $\mathbf{5}$ & 12,5 & 12,5 & 14,3 & 12,5 & $\mathbf{1 4 , 3}$ & 15,4 & 14,3 & 11,8 & 14,3 & 12,5 \\
\hline $\mathbf{6}$ & 31,3 & 31,3 & 35,7 & 31,3 & 35,7 & $\mathbf{3 8 , 5}$ & 35,7 & 31,3 & 35,7 & 31,3 \\
\hline $\mathbf{7}$ & 25,0 & 25,0 & 28,6 & 25,0 & 28,6 & 30,8 & $\mathbf{2 8 , 6}$ & 23,5 & 28,6 & 25,0 \\
\hline $\mathbf{8}$ & 25,0 & 25,0 & 28,6 & 25,0 & 28,6 & 30,8 & 28,6 & $\mathbf{2 3 , 5}$ & 28,6 & 25,0 \\
\hline $\mathbf{9}$ & 12,5 & 12,5 & 14,3 & 12,5 & 14,3 & 15,4 & 14,3 & 11,8 & $\mathbf{1 4 , 3}$ & 12,5 \\
\hline $\mathbf{1 0}$ & 37,5 & 37,5 & 42,9 & 37,5 & 42,9 & 46,2 & 42,9 & 35,3 & 42,9 & $\mathbf{3 7 , 5}$ \\
\hline
\end{tabular}


According to Table 3, the direct growth rates of the model variables, on the index scale 1-100, are ranked as follows: 1. Freight rates (42.9), 2. Bulk trade (38.5), 3. Innovations in maritime shipping (37.5), 4. Container trade (28.6), 5. Global economy (25.0), 6. Passenger trade (23.5), 7. LNG trade (14.3), 8. Shipbuilding (14.3), 9. Globalisation (12.5) and 10. Tanker trade (12.5).

Direct growth rates of the model variables will have higher values than their growth (see Table 2, growth 2010-2020), due to synergetic interrelation of all the variables (see Figure 1), as follows: Freight rates (growth $50 \leftrightarrow$ direct growth rates 71.4); Bulk trade (growth $25 \leftrightarrow$ direct growth rates 38.5); Innovations in maritime shipping (growth $30 \leftrightarrow$ direct growth rates 37.5); Container trade (growth $20 \leftrightarrow$ direct growth rates 28.6); Global economy (growth $20 \leftrightarrow$ direct growth rates 25.0); Passenger trade (growth $20 \leftrightarrow$ direct growth rates 23.5); LNG trade (growth $10 \leftrightarrow$ direct growth rates 14.3); Shipbuilding (growth $10 \leftrightarrow$ direct growth rates 14.3); Globalisation (growth $10 \leftrightarrow$ direct growth rates 12.5 ) and Tanker trade (growth $10 \leftrightarrow$ direct growth rates 12.5).

It is obvious that the greatest difference between the growth value and the value of direct growth rates will change the ranking of the variables compared to the ranking according to the values of their direct growth rates: 1. Freight rates (21.4), 2. Bulk trade (13.5), 3. Container trade (8.6), 4. Innovations in maritime shipping (7.5), 5. Global economy (5.0), 6. LNG trade (4.3), 7. Shipbuilding (4.3), 8. Passenger trade (3.5), 9. Globalisation (2.5) and 10. Tanker trade (2.5).

Taking into account all that has been discussed, it can be concluded that the direct growth rates of all variables of the model for global seaborne shipping market 2010 - 2020 have realistic chances to be implemented. In this way the scientific confirmation of the hypothesis of this research has been provided: on the basis of scientific insights into the global seaborne shipping market, it is possible to suggest a new information model for the development of the global seaborne shipping market for the period 2010 - 2020.

\section{CONCLUSION}

By the early 2020, the content of sulphur in fuel should be reduced to $0.5 \%$ globally, depending on feasibility studies and tests that have to be carried out by the end of 2018 at the latest. The feasibility tests refer to manufacturers" abilities, i.e. whether the production is able to meet the requirements and demand regarding low-sulphur fuels. If the tests produce negative results, the implementation of the regulations will have to be postponed until 2025. Fuel change is associated with a number of potential problems that require careful consideration.

The research has confirmed the initial hypothesis stating that "on the basis of scientific insights into the global seaborne shipping market, it is possible to suggest a new information model for the development of the global seaborne shipping market for the period 2010 - 2020." The design of the model for global seaborne shipping market 2010 - 2020 has been based on the most relevant variables, including: 1. Global economy, 2. Globalisation, 3. Freight rates, 4. Tanker trade, 5. LNG trade, 6. Bulk trade, 7. Container trade, 8. Passenger trade, 9. Shipbuilding and 10. Innovations in maritime shipping.

The quantification of the model has been performed on the basis of scientific and theoretical aspects of the mental-verbal insights into individual variables and their importance within the observed period, from 2010 to 2020 . The research produced direct growth rates of the variables on the index scale from 1 to 100: 1. Freight rates (71.4), 2. Bulk trade (38.5), 3. Innovations in maritime shipping (37.5), 4. Container trade (28.6), 5. Global economy (25.0), 6. Passenger trade (23.5), 7. LNG trade (14.3), 8. Shipbuilding (14.3), 9. Globalisation (12.5) and 10. Tanker trade (12.5).

Taking into consideration all that has been discussed, it can be concluded that the direct growth rates of all variables of the model for global seaborne shipping market 2010 - 2020 have realistic chances to be implemented. This also means that the hypothetical values of all variables of the model have been set realistically.

\section{REFERENCES}

Cerović, Lj. and Bašić, N., (2008), Analiza i prognoza ponude i potražnje svjetskog tankerskog brodarstva, Ekonomska misao i praksa DBK, 17(1), pp. 29 - 46.

CESA web page, (2010), available at: http://www.cesa-shipbuilding.org/

Columbia River Log Scaling \& Grading Bureau home page, available at: http://www. crls.com, [accessed 2 May 2015.].

Cruise Industry News, available at: http://www.cruiseindustrynews.com, [accessed 2 May 2015.]

DNV home page, available at: http://www.dnv.com, [accessed 2 May 2015.].

Dryships home page, available at: http://www.dryships.com/index.cfm?get=report, [accessed 2 May 2015.].

EMSA home page, available at: http://www.emsa.europa.eu, [accessed 2 May 2015.]. European Commission home page, http://ec.europa.eu/, [accessed 2 May 2015.].

Glavan, B., (1992), Ekonomika morskog brodarstva, Zagreb: Školska knjiga.

Hellenics Shipping News, available at: http://www.hellenicshippingnews.com, [accessed 2 May 2015.].

Hrvatska brodogradnja jadranbrod d.d. home page, available at: http://www.hb.hr, [accessed 2 May 2015.]

Intertanko home page, available at: http://www.intertanko.com, [accessed 2 May 2015.].

Izvješće Tankerske plovidbe d.d., (2009), available at: http://www.tankerska.hr/ skupstina_files/3._Godisnje_izvjesce_za_2009._godinu.pdf

Kunda, I., (2013), Utjecaj globalizacije u svjetskom gospodarstvu na tržištu morskog brodarstva, Diploma thesis, Rijeka: University of Rijeka, Faculty of Maritime Studies. 
LR home page, available at: http://www.Ir.com, [accessed 2 May 2015.]. Ne POSTOJI LINK

Mitrović, F., (2005), Pomorstvo i brodogradnja, Split: University of Split, Faculty of Maritime Studies.

Mitrović, F., (2006), Ekonomika brodarstva II, Split: University of Split, Faculty of Maritime Studies.

Ostojić, S., (2014), Svjetsko brodograđevno tržište, available at: http://hb.hr/wpcontent/uploads/2015/01/HBj-Svjetsko-trziste.pdf, [accessed 11 December 2016.].

Puljiz, V., (1998), Globalizacija i socijalna država, Zagreb: University of Zagreb, Study center of social work of Faculty of Law.

Research and Markets homepage, available at: http://www.researchandmarkets. com, [accessed 2 May 2015.].

RS Platou Economic Research AS, (2014), available at: http://www.clarksons.com/

Ship Cruise home page, available at: http://www.shipcruise.com, [accessed 2 May 2015.].

Statista - The statistics Portal homepage, available at: http://www.statista.com, [accessed 2 May 2015.].
Stopford, M., (2003), Maritime Economics, London: Routledge.

Stopford, M., (2009), COSCO World Shipping (China) Summit, Qingdao, China, November 12 - 13 .

Tijardović, I., (2012), Budućnost LNG tankera, Brodogradnja, 63(01), pp. 72-73. available at: http://www.hrbi.hr/brodogradnja/images/stories/2012/112/tijardovic. pdf

Udruga pomorskih kapetana - glasnik udruge, (2012), available at: http://www. upks.hr/glasnik_br24.pdf, [accessed 2 May 2015.].

UNSCIMEDIA homepage, available at: http://www.unscimedia.com, [accessed 2 May 2015.].

Vidučić, V., (2007), Pomorski turizam, Split: University of Split, Faculty of Maritime Studies.

Vidučić, V., (2011), Sustavi pomorskog tržišta, Split: University of Split.

Zelenika, R. and Pupovac, D., (2000), Od protekcionizma do liberalizacije transporta, Naše more, 47(5-6), pp. 181-194. 